\title{
SEA Ligation is accelerated at Midly Acidic pH. Application to the Formation of Difficult Peptide Junctions
}

Marine Cargoët, Vincent Diemer, Laurent Raibaut, Elizabeth Lissy, Benoît Snella, Vangelis Agouridas,* Oleg Melnyk*

UMR CNRS 8204, Université de Lille, Institut Pasteur de Lille, 1 rue du Pr Calmette, 59021 Lille Cedex, France.

Oleg.melnyk@ibl.cnrs.fr

http://olegmelnyk.cnrs.fr

\section{Summary}

The bis(2-sulfanylethyl)amido (SEA) ligation has been introduced in 2010 as a novel chemoselective peptide bond forming reaction. SEA ligation is a useful reaction for protein total synthesis that is complementary to the native chemical ligation (NCL). In particular, SEA ligation proceeds efficiently in a wide range of $\mathrm{pH}$, from neutral $\mathrm{pH}$ to $\mathrm{pH} 3-4$. Thus, the $\mathrm{pH}$ can be chosen to optimize the solubility of the peptide segments or final product. It can be also chosen to facilitate the formation of difficult junctions, since the rate of SEA ligation increases significantly by decreasing the $\mathrm{pH}$ from 7.2 to 4.0. Here we describe a protocol for SEA ligation at $\mathrm{pH} 5.5$ in the presence of 4-mercaptophenylacetic acid (MPAA) or at $\mathrm{pH} 4.0$ in the presence of a newly developed diselenol catalyst. The protocols describe the formation of a valyl-cysteinyl peptide bond between two model peptides.

Key words: Bis(2-sulfanylethyl)amido, SEA ligation, selenol catalysts, difficult junction, $\mathrm{pH}$

\section{Introduction}

Chemical synthesis can give access to complex proteins that biological systems can hardly produce or cannot produce at all. The capacity of modern chemical methods to access challenging protein targets can be illustrated by the recent synthesis of a chaperone protein, ${ }^{1}$ of catalytically active enzymes, ${ }^{2,3}$ or of functional ubiquitinated ${ }^{4}$ or sumoylated ${ }^{5,6}$ peptide protein conjugates. SEA ligation is a useful reaction for protein total synthesis in solution ${ }^{7}$ or on a water-compatible solid support ${ }^{8,9}$ that is complementary to the native chemical ligation $\left(\mathrm{NCL}^{10-12}\right)$. The bis(2-sulfanylethyl)amido (SEA) ligation consists in reacting a C-terminal bis(2-sulfanylethyl)amido peptide with an $\mathrm{N}$-terminal cysteinyl (Cys) peptide to produce a peptide featuring a native peptide bond to Cys (Figure 1A). ${ }^{13}$ This reaction proceeds in the presence of additives such as 4-mercaptophenylacetic acid (MPAA ${ }^{14}$ ) and tris(2- 
carboxyethyl)phosphine (TCEP). The arylthiol MPAA is used to catalyze the reaction probably through the formation of a transient arylthiolester intermediate, while TCEP activates the SEA group by reduction of the cyclic disulfide and ensures that the Cys thiols are in a reduced state.

Interestingly, the presence of the two thiol limbs in close proximity allows inactivating the SEA group by formation of an intramolecular disulfide bond. The SEA group in the form of its cyclic disulfide (SEA ${ }^{\text {off }}$ ) is highly stable during HPLC purification, storage or in solution in the presence of strong nucleophiles such as piperidine, ${ }^{15}$ aqueous bases ${ }^{8}$ or weakly reducing thiols such as MPAA at neutral $\mathrm{pH} .{ }^{16}$ Due to the latter property, the SEA ${ }^{\text {off }}$ group can be used as a latent thioester during the NCL reaction provided that strong reducing agents such as TCEP or dithiothreitol (DTT) are not included in the reaction mixture..$^{5,8,16-19}$

The SEA group is one of the first $N, S$-acyl shift system or thioester surrogate that has been shown to react with Cys peptides at neutral $\mathrm{pH} .{ }^{13}$ The mechanism of SEA ligation is not fully understood and the underlying factors for this unusual reactivity remain to be established. Interestingly, the rate of SEA ligation increases significantly by decreasing the pH from 7.2 to 5.5 (Figure 1B, see Note 1). This property can be exploited for forging difficult junctions such as the valyl-cysteinyl bond found in peptide $4 \mathrm{~b}$ (Fig. $1 \mathrm{~A}, \mathrm{X}=\mathrm{Val}$ ). The formation of such junctions by SEA-mediated ligation can be accomplished in two ways that are described in this protocol: by SEA-mediated ligation at $\mathrm{pH} 5.5$ in the presence of MPAA (Protocol 1, Fig. 1A, see Notes 2 and 3), or by SEA-mediated ligation at pH 4.0 in the presence of diselenide 5 (Protocol 2, Fig. 2A). ${ }^{20} \mathrm{Fig}$. 2B shows that the reaction in the latter conditions proceeds faster than for the MPAA-catalyzed ligation at $\mathrm{pH}$ 5.5. Mechanistic studies have demonstrated that diselenide-based catalysts of type $\mathbf{5} \mathbf{a}-\mathbf{b}$, which are reduced in situ by TCEP into diselenols $\mathbf{6} \mathbf{a}-\mathbf{b}$ that are the active catalyst species, promote thiol-thioester exchanges which are ratelimiting at the working $\mathrm{pH}$ of $4.0 .^{20}$ 
A)

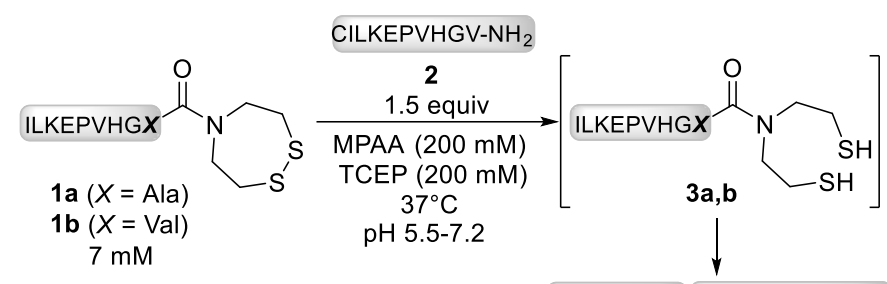

ILKEPVHGXCILKEPVHGV-NH ${ }_{2}$

4a $(X=$ Ala $)$

4b $(X=$ Val $)$

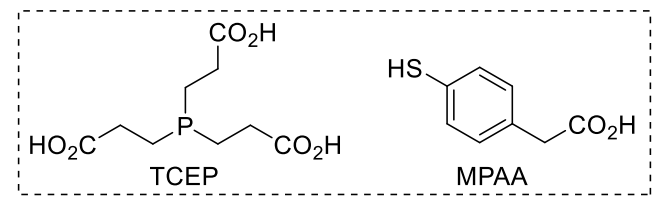

B)

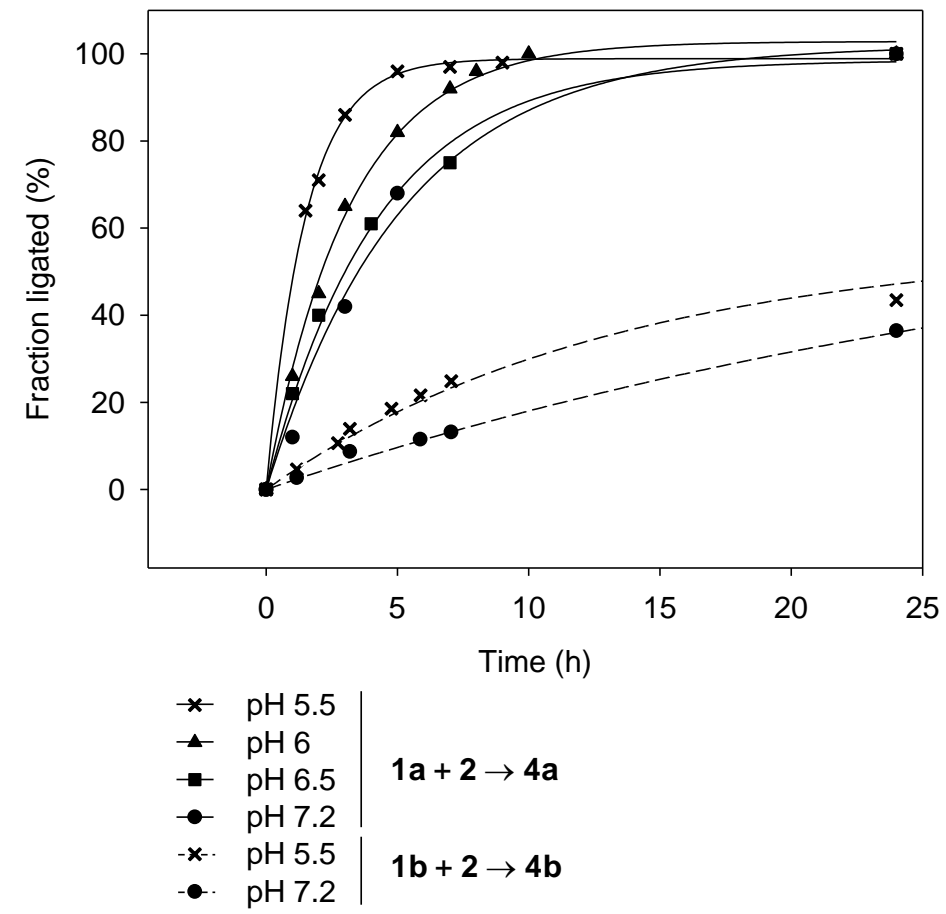

Fig. 1. Principle of SEA ligation (A) and the effect of the $\mathrm{pH}$ on the rate of SEA ligation (B). 


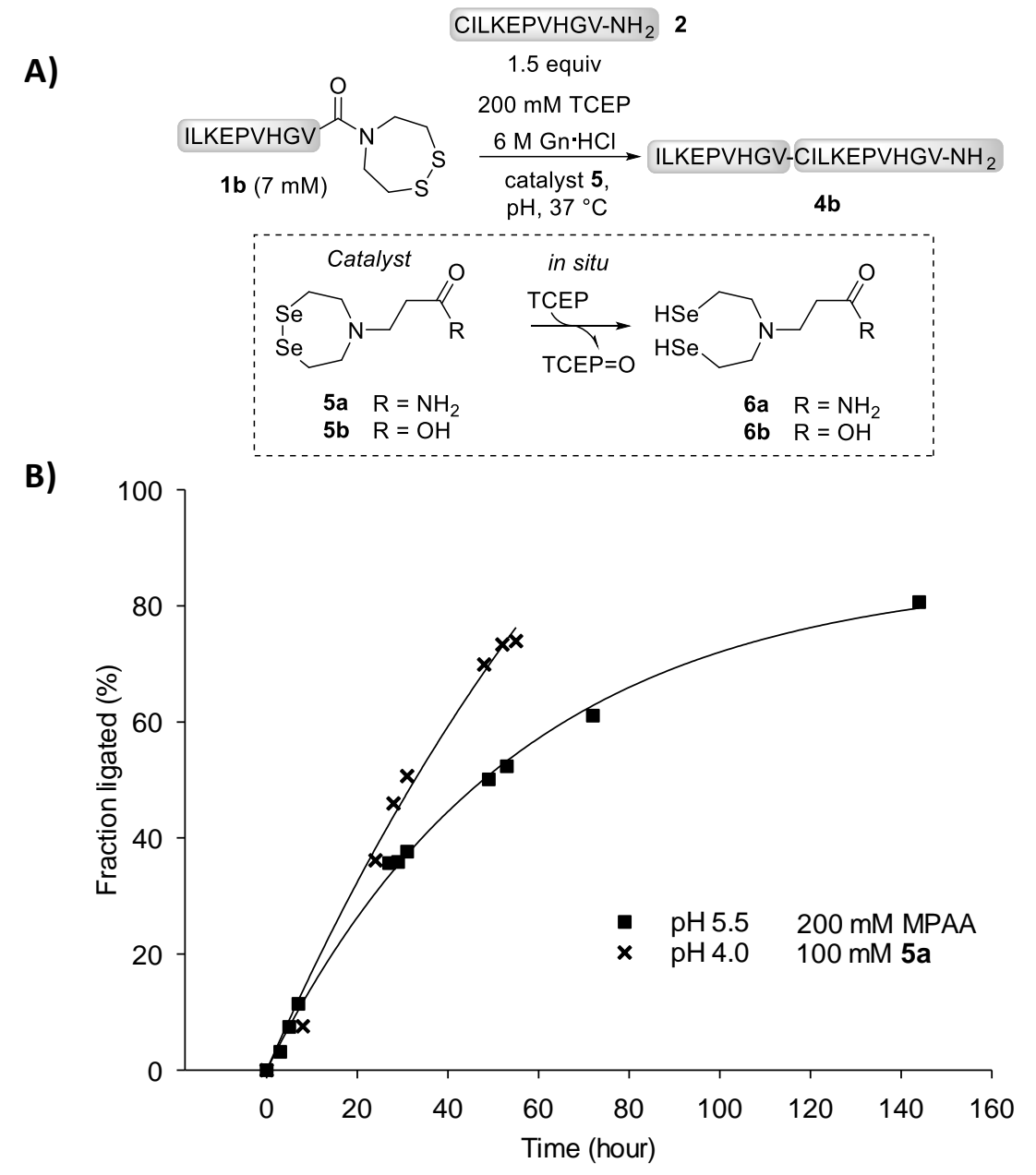

Fig. 2. Catalysis of SEA-mediated ligation at $\mathrm{pH} 4.0$ by diselenide catalysts $\mathbf{5 a - b}$.

\section{Materials}

All organic solvents and chemicals used in this protocol should be handled inside a chemical fume hood with appropriate personal protective equipment (lab coat, gloves and protective glasses). TFA is strongly corrosive and toxic.

\subsection{General}

1. Deionized water

\subsection{HPLC analysis \& purification}

1. Analytical HPLC system (Waters Alliance 2695, UV 2996 Detector, $215 \mathrm{~nm}$ ).

2. Semi-preparative HPLC system (Waters 600 controller, UV 2487 Detector, $215 \mathrm{~nm}$, TL 105 HPLC column heater). 
3. Analytical HPLC column: Waters XBridge BEH300 C18 reverse-phase column $(4.6$ x $150 \mathrm{~mm}$; pore size $300 \AA ̊$; particle size: $3.5 \mu \mathrm{m}$ ).

4. Semi-preparative HPLC column: Waters XBridge BEH300 C18 reverse-phase column $(10 \times 250$ $\mathrm{mm}$; pore size $300 \AA$; particle size: $5 \mu \mathrm{m}$ ).

5. Acetonitrile for HPLC (ACN, Carlo Erba, Cat. No. 412392000).

6. Trifluoroacetic acid (TFA; Biosolve, Cat. No. 20233301).

7. TFA $10 \%$ (vol/vol) in water. Add $10 \mathrm{~mL}$ of TFA carefully to $90 \mathrm{~mL}$ of deionized water.

8. Eluent A for semi-preparative HPLC. TFA $0.1 \%$ (vol/vol) in deionized water. Add $10 \mathrm{~mL}$ of TFA $10 \%(\mathrm{vol} / \mathrm{vol})$ in water to $990 \mathrm{~mL}$ of deionized water.

9. Eluent B for semi-preparative HPLC. HPLC $80 \%$ (vol/vol) containing $0.1 \%$ (vol/vol) TFA. Add $10 \mathrm{~mL}$ of TFA $10 \%$ (vol/vol) in water to $990 \mathrm{~mL}$ of ACN $80 \%$ (vol/vol) in deionized water.

\subsection{Lyophilization}

1. Lyophilizer (Christ Gamma 2-20) equipped with a manifold.

2. Lyophilizer flasks (VWR, $300 \mathrm{~mL}$, Cat. No. 88516; $600 \mathrm{~mL}$, Cat. No. 88517).

3. Liquid nitrogen

4. Dewar

\subsection{MALDI-TOF analysis}

1. $\alpha$-cyano-4-hydroxycinnamic acid (Aldrich, Cat. No. 476870).

2. MALDI-TOF mass spectrometer (Autoflex Speed, Bruker).

3. A solution of $\alpha$-cyano-4-hydroxycinnamic acid $10 \mathrm{mg} / \mathrm{mL}$ in $50 \%$ aqueous acetonitrile containing $0.1 \%$ TFA.

\subsection{SEA ligation}

1. 4-mercaptophenylacetic acid (MPAA; Alfa Aesar, Cat. No. H27658).

2. Disodium hydrogen phosphate dodecahydrate $\left(\mathrm{Na}_{2} \mathrm{HPO}_{4} \cdot 12 \mathrm{H}_{2} \mathrm{O}\right.$, Merck, Cat. No. 6576).

3. TFA $10 \%$ (vol/vol) in water. Add $10 \mathrm{~mL}$ of TFA carefully to $90 \mathrm{~mL}$ of deionized water.

4. Nitrogen gas $\left(\mathrm{O}_{2}<3 \mathrm{ppm}\right.$, Air Liquide)

5. Sodium dihydrogen phosphate dihydrate $\left(\mathrm{NaH}_{2} \mathrm{PO}_{4} \cdot 2 \mathrm{H}_{2} \mathrm{O}\right.$, Prolabo, Cat. No. 28015294)

6. Sodium hydroxide ( $\mathrm{NaOH}$; Merck, Cat. No. 1.06498.1000)

7. Hydrochloric acid ( $\mathrm{HCl}$; Sigma Aldrich, Cat. No. 32-0331-500 mL)

8. Tris(2-carboxyethyl)phosphine hydrochloride (TCEP.HCl; Aldrich, Cat. No. C4706-10G)

9. Conical tubes $(15 \mathrm{~mL}, 50 \mathrm{~mL})$

10. Glove box (Jacomex) equipped with (see Note 4): a magnetic stirrer, a block heater $\left(37^{\circ} \mathrm{C}\right)$, a set of adjustable pipettes $(0.5-10,2-20,10-50,10-100,100-1,000 \mu \mathrm{L}$, Eppendorf), a pH meter (Eutech instrument) and a vortex shaker.

11. Magnetic stir bars 
12. Microfuge tubes ( $1.5 \mathrm{~mL}$ safe-lock tubes; Eppendorf)

13. Pipette tips, $0.5-10,2-20,20-200,100-1,000 \mu \mathrm{L}$ (VWR)

14. $0.2 \mathrm{M}$ sodium phosphate buffer $\mathrm{pH}$ 7.2. Prepare $36 \mathrm{~mL}$ of a $0.2 \mathrm{M}$ solution of disodium hydrogen phosphate dodecahydrate in deionized water. Prepare $10 \mathrm{~mL}$ of a $0.2 \mathrm{M}$ solution of sodium dihydrogen phosphate dihydrate in deionized water. Mix the two solutions and verify the $\mathrm{pH}$.

15. pH paper (Merck Millipore, universal indicator 1-14, Cat. No 1.10962.0003)

16. Glacial acetic acid (Carbo Erba, 1 L, Cat. No. 401422)

17. Diethyl ether (Sigma Aldrich, Cat. No 32203-2.5L)

\section{Methods}

\section{Protocol 1. SEA-ligation at pH 5.5 catalyzed by MPAA}

1. Weigh $4.56 \mathrm{mg}$ ( 1 eq., $3.15 \mu \mathrm{mol}$ ) of $S E A^{\text {off }}$ peptide $\mathbf{1 b}$ in a $1.5-\mathrm{mL}$ microfuge tube.

2. Weigh $6.83 \mathrm{mg}(1.5$ eq., $4.72 \mu \mathrm{mol}$ ) of cysteinyl peptide 2 in a $1.5-\mathrm{mL}$ microfuge tube. Add a magnetic stir bar to the microfuge tube.

3. Weigh $33.64 \mathrm{mg}(0.2000 \mathrm{mmol})$ of MPAA in a $1.5-\mathrm{mL}$ microfuge tube.

4. Weigh $57.33 \mathrm{mg}(0.200 \mathrm{mmol})$ of TCEP in a $1.5-\mathrm{mL}$ microfuge tube.

5. Prepare $2 \mathrm{~mL}$ of $0.1 \mathrm{M}$ sodium phosphate buffer ( $\mathrm{pH} 7.2$ ) by diluting $1 \mathrm{~mL}$ of $0.2 \mathrm{M}$ sodium phosphate $(\mathrm{pH} 7.2)$ with $1 \mathrm{~mL}$ of deionized water in a 15- $\mathrm{mL}$ plastic tube.

6. Transfer $1 \mathrm{~mL}$ of TFA $10 \%$ (vol/vol), $1 \mathrm{~mL}$ of $\mathrm{HCl} 1 \mathrm{~N}$ and $1 \mathrm{~mL}$ of $\mathrm{NaOH} 6 \mathrm{~N}$ in three different 1.5-mL microfuge tubes.

7. Cap all the tubes and transfer them to the glove box under nitrogen atmosphere (see Note 5).

8. Add $1 \mathrm{~mL}$ of the sodium phosphate buffer from step 5 to the microfuge tube containing TCEP (see Step 4). Vortex until dissolution of the TCEP and then transfer this solution to the microfuge tube containing MPAA (see step 3). Add $\mathrm{NaOH} 6 \mathrm{~N}$ with the micropipette and vortex until dissolution of the MPAA (see Note 6). The final reagent concentration is $181 \mathrm{mM}$ for MPAA and $181 \mathrm{mM}$ for TCEP.

9. Add $450 \mu \mathrm{L}$ of the solution prepared in Step 8 to the microfuge tube containing the SEA ${ }^{\text {off }}$ peptide $\mathbf{1 b}$ (see step 1). Vortex to dissolve the peptide and then add this solution to the microfuge tube containing the cysteinyl peptide $\mathbf{2}$ (see step 2). Vortex to dissolve the peptide.

10. Measure the $\mathrm{pH}$ of the solution prepared in Step 9, and adjust to $\mathrm{pH} 5.5$ (see Note 7) by adding $\mathrm{NaOH} 6 \mathrm{~N}$ or $\mathrm{HCl} 1 \mathrm{~N}$ with the micropipette $(2-20 \mu \mathrm{L}$ ) (see Note 8). The final peptide concentration is $\sim 6.7 \mathrm{mM}$ for the SEA ${ }^{\text {off }}$ peptide $\mathbf{1 b}$ and $10 \mathrm{mM}$ for the cysteinyl peptide 2 .

11. Place the reaction tube from step 10 in a heating block kept at $37^{\circ} \mathrm{C}$ and stir with a magnetic stirrer.

12. To monitor the ligation reaction (just after preparing the reaction mixture at Step 10 and every hour until $8 \mathrm{~h}$ of reaction and after 24 h, 48 h, $72 \mathrm{~h}$ and after 7 days, see Note 9), transfer $10 \mu \mathrm{L}$ of the reaction mixture to a microfuge tube and quench the reaction by acidifying the sample with $20 \mu \mathrm{l}$ of TFA $10 \%(\mathrm{vol} / \mathrm{vol})$ in deionized water. Vortex and remove the sample from the glove box.

13. Remove MPAA present in the reaction mixture by extracting the aqueous phase with $1 \mathrm{~mL}$ of diethyl ether. Remove the diethyl ether phase with a Pasteur pipette (see Note 10).

14. Repeat Step 13 twice.

15. Inject $15 \mu \mathrm{l}$ of the aqueous sample isolated in Step 14 into the analytical HPLC system to confirm that the starting peptide segments have been consumed to produce the ligation product $\mathbf{4 b}$ (see Note $\mathbf{1 1}$ ). 
16. After 7 days, remove the reaction tube from the glove box.

17. Transfer the contents of the reaction tube into a $5-\mathrm{mL}$ microfuge tube.

18. Add $550 \mu \mathrm{L}$ of deionized water to the reaction mixture containing the crude peptide $\mathbf{4 b}$ and $75-\mu \mathrm{L}$ of glacial acetic acid to a final concentration of $5-10 \% \mathrm{vol} / \mathrm{vol}$ with a micropipette to acidify the aqueous solution down to a $\mathrm{pH}$ of 2-3 ( $\mathrm{pH}$ paper).

19. Extract the MPAA from the aqueous phase with $3 \mathrm{~mL}$ of diethyl ether as done in step 13. Remove the diethyl ether phase with a Pasteur pipette (see Note 10).

20. Repeat Step 19 twice.

21. Remove the dissolved diethyl ether by nitrogen bubbling ( $\sim 5 \mathrm{~min}$ )

22. Purify the target peptide $\mathbf{4 b}$ on a Waters XBridge BEH300 C18 reverse-phase column $(10 \times 250$ mm; pore size $300 \AA ̊$; particle size: $5 \mu \mathrm{m}$ ) using a semipreparative HPLC system; Gradient : $0 \%$ eluent $B$ in eluent $A$ to $20 \%$ (vol/vol) eluent $B$ in eluent $A$ over $10 \mathrm{~min}$, and then $20 \%$ (vol/vol) eluent $B$ in eluent $A$ to $40 \%$ (vol/vol) eluent B in eluent $A$ over 50 min (UV detection at 215 $\mathrm{nm})$. Analyze the fractions using the MALDI-TOF spectrometer. For this mix $1 \mu \mathrm{L}$ of the $\alpha$ cyano-4-hydroxycinnamic acid solution with $1 \mu \mathrm{L}$ of the sample on the MALDI plate and let dry at room temperature in air.

23. Pool the pure fractions in a $50 \mathrm{~mL}$ plastic tube, freeze the solution with liquid nitrogen and Iyophilize it for 2 days. The reaction yielded $3.55 \mathrm{mg}$ (55\% by taking into account the samples used for analytical HPLCS) of peptide 4b. MALDI-TOF analysis: [M+H] ${ }^{+}$calcd. 2066.2 (monoisotopic), found 2066.2.

\section{Protocol 2. SEA-ligation at pH 4.0 catalyzed by diselenide 7b}

1. Weigh $5.06 \mathrm{mg}$ ( 1 eq., $3.49 \mu \mathrm{mol}$ ) of $S E A^{\text {off }}$ peptide $\mathbf{1 b}$ in a $1.5-\mathrm{mL}$ microfuge tube.

2. Weigh $7.53 \mathrm{mg}$ (1.5 eq., $5.23 \mu \mathrm{mol}$ ) of cysteinyl peptide 2 in a $1.5-\mathrm{mL}$ microfuge tube. Add a magnetic stir bar to the microfuge tube.

3. Weigh $20.76 \mathrm{mg}$ of catalyst $\mathbf{5 b}(49.9 \mu \mathrm{mol})$ in a $1.5-\mathrm{mL}$ microfuge tube (see Note $\mathbf{1 2})$.

4. Weigh $28.67 \mathrm{mg}(0.1 \mathrm{mmol})$ of TCEP in a $1.5-\mathrm{mL}$ microfuge tube.

5. Weigh $286.59 \mathrm{mg}$ of $\mathrm{Gn} \cdot \mathrm{HCl}(1.200 \mathrm{mmol})$ in a $1.5-\mathrm{mL}$ microfuge tube.

6. Prepare $1 \mathrm{~mL}$ of $0.1 \mathrm{M}$ sodium phosphate buffer ( $\mathrm{pH} 7.2$ ) by diluting $0.5 \mathrm{~mL}$ of $0.2 \mathrm{M}$ sodium phosphate $(\mathrm{pH} 7.2)$ with $0.5 \mathrm{~mL}$ of deionized water in a $1.5-\mathrm{mL}$ microfuge tube.

7. Transfer $1 \mathrm{~mL}$ of TFA $0.1 \%$ in deionized water (vol/vol), $1 \mathrm{~mL}$ of $\mathrm{HCl} 1 \mathrm{~N}$ and $1 \mathrm{~mL}$ of $\mathrm{NaOH} 6 \mathrm{~N}$ in three different $1.5-\mathrm{mL}$ microfuge tubes.

8. Cap all the tubes and transfer them to the glove box under nitrogen atmosphere (see Note 5).

9. Add $300 \mu \mathrm{L}$ of the sodium phosphate buffer from step 6 to the microfuge tube containing $\mathrm{Gn} \cdot \mathrm{HCl}$ (see Step 5). Vortex until dissolution of the guanidinium salt and transfer this solution to the microfuge tube containing TCEP (see step 4). Vortex again until dissolution of TCEP and transfer the solution to the microfuge tube containing catalyst $\mathbf{5 b}$ (see step 3 ).

10. The $\mathrm{pH}$ of the solution is raised to 4.01 by addition of a $\mathrm{NaOH} 6 \mathrm{~N}$ aqueous solution $(34 \mu \mathrm{L})$. The final reagent concentration is $187 \mathrm{mM}$ for TCEP and $94 \mathrm{mM}$ for catalyst $\mathbf{5 b}$.

11. Add $499 \mu \mathrm{L}$ of the solution prepared in Step 10 to the microfuge tube containing the SEA ${ }^{\text {off }}$ peptide $\mathbf{1 b}$ (see step 1). Vortex to dissolve the peptide and then transfer this solution to the microfuge tube containing the cysteinyl peptide $\mathbf{2}$ (see step 2). Vortex to dissolve the peptide.

12. Place the reaction tube in a heating block kept at $37^{\circ} \mathrm{C}$ and stir with a magnetic stirrer (see Note 13). 
13. To monitor the ligation reaction (just after preparing the reaction mixture at Step 11 and at regular time intervals until completion of the reaction), transfer $1 \mu \mathrm{L}$ of the reaction mixture to a microfuge tube containing $50 \mu \mathrm{l}$ of TFA $0.1 \%$ ( $\mathrm{vol} / \mathrm{vol})$ in deionized water. Vortex and remove the sample from the glove box (see Note 14).

14. Inject $30 \mu \mathrm{L}$ of the reaction sample isolated in Step 13 into the analytical HPLC system to confirm that the starting peptide segments have been consumed to produce the ligation product $\mathbf{4 b}$.

15. After completion of the reaction, remove the reaction tube from the glove box.

16. Transfer the contents of the reaction tube into a $5-\mathrm{mL}$ microfuge tube and add $5 \mathrm{~mL}$ of a $0.1 \%$ TFA solution in deionized water $(\mathrm{v} / \mathrm{v})$. Filter the crude solution through a disposable syringe filter before injection.

17. Purify the target peptide $4 \mathbf{b}$ on a Waters XBridge BEH300 C18 reverse-phase column $(10 \times 250$ $\mathrm{mm}$; pore size $300 \AA \AA$; particle size: $5 \mu \mathrm{m}$ ) using a semipreparative HPLC system; Gradient: $0 \%$ eluent $B$ in eluent $A$ to $20 \%$ (vol/vol) eluent $B$ in eluent $A$ over $5 \mathrm{~min}$, and then $20 \%$ (vol/vol) eluent $B$ in eluent $A$ to $35 \%$ (vol/vol) eluent B in eluent A over 60 min (UV detection at 215 $\mathrm{nm})$. Analyze the fractions using the MALDI-TOF spectrometer. For this mix $1 \mu \mathrm{L}$ of the $\alpha$ cyano-4-hydroxycinnamic acid solution with $1 \mu \mathrm{L}$ of the sample on the MALDI plate and let dry at room temperature in air.

18. Pool the pure fractions in a $50 \mathrm{~mL}$ plastic tube, freeze the solution with liquid nitrogen and lyophilize it for 2 days. The reaction yielded $4.69 \mathrm{mg}(51 \%)$ of peptide $4 \mathbf{b}$. MALDI-TOF analysis: $[\mathrm{M}+\mathrm{H}]^{+}$calcd. 2066.2 (monoisotopic), found 2066.5.

\section{Notes}

1. The SEA group can be introduced on the side-chain of aspartic or glutamic acid residues for accessing branched or tail to side-chain cyclized peptides. In this case also, a significant acceleration of the SEA ligation process has been noticed by lowering the $\mathrm{pH}$ from 7.3 to 5.5. ${ }^{15}$

2. For an application of SEA ligation at $\mathrm{pH} 5.5$ to the synthesis of large cyclic peptides see reference ${ }^{21}$.

3. Peptidyl prolyl thioesters, i.e. peptide ${ }_{1}$-AA-Pro-SR $(R=$ alkyl), are known to be poorly reactive toward Cys peptides (Cys-peptide $e_{2}$ ). ${ }^{22} A$ similar observation has been made for peptidyl prolyl SEA peptides (peptide ${ }_{1}$-AA-Pro-SEA) ${ }^{23}$ However, the rate of the SEA ligation process can be increased significantly by raising the temperature to $65^{\circ} \mathrm{C}$ and conducting the experiment at $\mathrm{pH}$ 5.5. Moreover, we have also shown that the target ligation product of peptidyl prolyl thioesters or peptidyl prolyl SEA peptides with Cys peptides, i.e. peptide ${ }^{-}$ AA-Pro-Cys-peptide 2 , can be contaminated by substantial amounts of a two amino acids deletion side-product, i.e. peptide ${ }_{1}$-Cys-peptide ${ }_{2}$, corresponding to the loss of AA-Pro residues. Side-product formation is probably due to the degradation of the peptidyl prolyl SEA or thioester peptide through intramolecular cyclization and formation of a transient $\mathrm{N}$-peptidyl diketopiperazine intermediate. Interestingly, conducting the SEA ligation process at $\mathrm{pH} 5.5$ allowed reducing significantly the proportion of the deletion sideproduct in comparison with the peptidyl prolyl thioester analog used at $\mathrm{pH}$ 7.1. 
4. The glove box used in this work allows performing the ligation experiments in a nitrogen atmosphere with oxygen levels below $10 \mathrm{ppm}$. Alternatively, an inflatable plastic glove bag can be used. Very low oxygen levels are not mandatory for performing SEA ligations although it is recommended when long reaction times are needed as for the synthesis of peptide $\mathbf{4 b} .{ }^{22}$ Molecular oxygen oxidizes thiolate species into disulfides, which are in turn reduced by TCEP. The net result of this process is that molecular oxygen consumes TCEP which allows maintaining the thiols in a reduced form. If the HPLC chromatograms of the reaction mixture show the formation of disulfides, and in particular of mixed disulfides with MPAA (see reference ${ }^{19}$ ), more TCEP must be added to the reaction mixture.

5. The tubes must be tightly capped during transfer into the glove box, which requires purging the airlock by pumping and filling with nitrogen.

6. TCEP hydrochloride is a highly acidic reagent. Dissolution of TCEP in the phosphate buffer results in a significant decrease of the $\mathrm{pH}$ well below $\mathrm{pH}$ 5.5. MPAA is poorly soluble in these conditions. MPAA is highly soluble in water at and above $\mathrm{pH} 5.5$ due to the ionization of its carboxylic acid group (the $p K_{a}$ of MPAA is 6.6). ${ }^{14}$ MPAA will therefore solubilize gradually upon addition of $\mathrm{NaOH}$ and vortexing. At this stage, a precise control of the $\mathrm{pH}$ is not mandatory. However, the addition of $\mathrm{NaOH}$ must be done carefully to avoid a significant increase of the $\mathrm{pH}$, that would require the addition of large volumes of $\mathrm{HCl}$ at Step 10.

7. SEA ligation well below $\mathrm{pH} 5.5$ in the presence of MPAA is feasible and can be very useful. For example, SEA ligation at pH 3.0 allowed the synthesis of $O$-acyl isodipeptides without any protection on the $O$-acyl isodipeptide units because at this $\mathrm{pH}$ the free amino group of the $\mathrm{O}$-acyl isodipeptide units is protected by protonation. ${ }^{24}$ The solubility of MPAA at $\mathrm{pH}$ 3.0 in the presence of $0.6 \mathrm{M}$ guanidinium hydrochloride is $\sim 30 \mathrm{mM}^{24}$

8. The addition of $\mathrm{NaOH} 6 \mathrm{~N}$ (or $\mathrm{HCl} 1 \mathrm{~N}$ ) must be done carefully otherwise the $\mathrm{pH}$ can raise significantly above (or decrease well below) pH 5.5 .

9. Ligation at valine is notoriously difficult, see ref ${ }^{22}$.

10. The large excess of MPAA used for the SEA ligation must be extracted with diethyl ether before running the analytical or the semi-preparative HPLC systems. This arylthiol absorbs strongly at the wavelengths used for the UV detection by the HPLC systems and can coelute with the target peptide. The efficient extraction of MPAA requires the acidification of the mixture well below its pKa. This can be achieved by adding TFA $10 \%$ (vol/vol) to the reaction mixture before the extraction. An alternative is to use acetic acid $(5-10 \% \mathrm{vol} / \mathrm{vol}$ final concentration).

11. MPAA catalyzes the SEA ligation process through probably the in situ formation of an arylthioester peptide segment by a thiol-thioester exchange mechanism. ${ }^{25}$ Usually, the arylthiolester peptide derived from the SEA peptide reacts quickly with the cysteinyl component so that it is usually not observed in the HPLC traces of the crude ligation mixture. Nevertheless, it can be observed when the SEA peptide is used in excess relative to the Cys peptide.

12. Catalysts $\mathbf{5 a}$ or $\mathbf{5 b}$ can be used without any significant difference with regard to the kinetics and final yield of the ligation reaction, see ref ${ }^{20}$.

13. Deselenization of the catalyst during ligation is insignificant. ${ }^{20}$ 
14. The use of type $\mathbf{5}$ diselenide catalysts in the reaction considerably simplifies the work-up as they are highly soluble in water. Contrary to MPAA, no extractive workup is necessary prior to HPLC injection.

\section{Acknowledgements}

This study was supported by the Centre National de la Recherche Scientifique (CNRS), the University of Lille Nord de France, Institut Pasteur de Lille.

\section{References}

(1) Weinstock, M. T.; Jacobsen, M. T.; Kay, M. S. Synthesis and Folding of a Mirror-Image Enzyme Reveals Ambidextrous Chaperone Activity. Proc. Natl. Acad. Sci. U. S. A. 2015, 111, 1167911684.

(2) Wintermann, F.; Engelbrecht, S. Reconstitution of the Catalytic Core of F-ATPase $(\mathrm{A} \beta)_{3} \gamma$ from Escherichia coli Using Chemically Synthesized subunit $\gamma$. Angew. Chem. Int. Ed. 2013, 52, 13091313.

(3) Lahiri, S.; Brehs, M.; Olschewski, D.; Becker, C. F. Total Chemical Synthesis of an Integral Membrane Enzyme: Diacylglycerol Kinase from Escherichia coli. Angew. Chem. Int. Ed. 2011, 50, 3988-3992.

(4) Siman, P.; Karthikeyan, S. V.; Nikolov, M.; Fischle, W.; Brik, A. Convergent Chemical Synthesis of Histone H2B Protein for the Site-Specific Ubiquitination at Lys34. Angew. Chem. Int. Ed. 2013, 52, 8059-8063.

(5) Boll, E.; Drobecq, H.; Ollivier, N.; Blanpain, A.; Raibaut, L.; Desmet, R.; Vicogne, J.; Melnyk, O. One-Pot Chemical Synthesis of Small Ubiquitin-Like Modifier (SUMO) Protein-Peptide Conjugates Using Bis(2-Sulfanylethyl)Amido Peptide Latent Thioester Surrogates Nat. Protoc. 2015, 10, 269-292.

(6) Boll, E.; Drobecq, H.; Ollivier, N.; Raibaut, L.; Desmet, R.; Vicogne, J.; Melnyk, O. A Novel PEGBased Solid Support Enables the Synthesis of $>50$ Amino-Acid Peptide Thioesters and the Total Synthesis of a Functional SUMO-1 Peptide Conjugate. Chem. Sci. 2014, 5, 2017-2022.

(7) Raibaut, L.; Ollivier, N.; Melnyk, O. Sequential Native Peptide Ligation Strategies for Total Chemical Protein Synthesis. Chem. Soc. Rev. 2012, 41, 7001-7015.

(8) Raibaut, L.; Adihou, H.; Desmet, R.; Delmas, A. F.; Aucagne, V.; Melnyk, O. Highly Efficient Solid Phase Synthesis of Large Polypeptides by Iterative Ligations of Bis(2-Sulfanylethyl)Amido (SEA) Peptide Segments. Chem. Sci. 2013, 4, 4061-4066.

(9) Raibaut, L.; El Mahdi, O.; Melnyk, O. Solid Phase Protein Chemical Synthesis. Top. Curr. Chem. 2015, 363, 103-154.

(10) Dawson, P. E.; Muir, T. W.; Clark-Lewis, I.; Kent, S. B. H. Synthesis of Proteins by Native Chemical Ligation. Science 1994, 266, 776-779.

(11) Kent, S. B. H. Total Chemical Synthesis of Proteins. Chem. Soc. Rev. 2009, 38, 338-351.

(12) Agouridas, V.; El Mahdi, O.; Diemer, V.; Cargoet, M.; Monbaliu, J.-C. M.; Melnyk, O. Native Chemical Ligation and Extended Methods. Mechanisms, Catalysis, Scope and Limitations. Chem. Rev. 2019, 12, 7328-7443.

(13) Ollivier, N.; Dheur, J.; Mhidia, R.; Blanpain, A.; Melnyk, O. Bis(2-Sulfanylethyl)Amino Native Peptide Ligation. Org. Lett. 2010, 12, 5238-5241. 
(14) Johnson, E. C.; Kent, S. B. H. Insights into the Mechanism and Catalysis of the Native Chemical Ligation Reaction. J. Am. Chem. Soc. 2006, 128, 6640-6646.

(15) Boll, E.; Dheur, J.; Drobecq, H.; Melnyk, O. Access to Cyclic or Branched Peptides Using Bis(2Sulfanylethyl)Amido Side-Chain Derivatives of Asp and Glu. Org. Lett. 2012, 14, 2222-2225.

(16) Ollivier, N.; Vicogne, J.; Vallin, A.; Drobecq, H.; Desmet, R.; El-Mahdi, O.; Leclercq, B.; Goormachtigh, G.; Fafeur, V.; Melnyk, O. A One-Pot Three-Segment Ligation Strategy for Protein Chemical Synthesis. Angew. Chem. Int. Ed. 2012, 51, 209-213.

(17) Raibaut, L.; Drobecq, H.; Melnyk, O. Selectively Activatable Latent Thiol and Selenolesters Simplify the Access to Cyclic or Branched Peptide Scaffolds. Org. Lett. 2015, 17, 3636-3639.

(18) Melnyk, O.; Agouridas, V. Perhydro-1,2,5-Dithiazepine. e-EROS 2014, No rn01723.

(19) Raibaut, L.; Vicogne, J.; Leclercq, B.; Drobecq, H.; Desmet, R.; Melnyk, O. Total Synthesis of Biotinylated N Domain of Human Hepatocyte Growth Factor. Bioorg. Med. Chem. 2013, 21, 3486-3494.

(20) Cargoët, M.; Diemer, V.; Snella, B.; Desmet, R.; Blanpain, A.; Drobecq, H.; Agouridas, V.; Melnyk, O. Catalysis of Thiol-Thioester Exchange by Water-Soluble Alkyldiselenols Applied to the Synthesis of Peptide Thioesters and SEA-Mediated Ligation. J. Org. Chem. 2018, 83, 1258412594.

(21) Boll, E.; Ebran, J. P.; Drobecq, H.; El-Mahdi, O.; Raibaut, L.; Ollivier, N.; Melnyk, O. Access to Large Cyclic Peptides by a One-Pot Two-Peptide Segment Ligation/Cyclization Process. Org. Lett. 2015, 17, 130-133.

(22) Hackeng, T. M.; Griffin, J. H.; Dawson, P. E. Protein Synthesis by Native Chemical Ligation: Expanded Scope by Using Straightforward Methodology. Proc. Natl. Acad. Sci. U. S. A. 1999, 96, 10068-10073.

(23) Raibaut, L.; Seeberger, P.; Melnyk, O. Bis(2-Sulfanylethyl)Amido Peptides Enable Native Chemical Ligation at Proline and Minimize Deletion Side-Product Formation. Org. Lett. 2013, 15, 5516-5519.

(24) Desmet, R.; Pauzuolis, M.; Boll, E.; Drobecq, H.; Raibaut, L.; Melnyk, O. Synthesis of Unprotected Linear or Cyclic O-Acyl Isopeptides in Water Using Bis(2-Sulfanylethyl)Amido Peptide Ligation. Org. Lett. 2015, 17, 3354-3357.

(25) Dawson, P. E.; Churchill, M. J.; Ghadiri, M. R.; Kent, S. B. H. Modulation of Reactivity in Native Chemical Ligation through the Use of Thiol Additives. J. Am. Chem. Soc. 1997, 119, 4325-4329. 